\title{
EUROPEAN IPO MARKET. GLOBAL AND REGIONAL STOCK EXCHANGES
}

\author{
Sofya Glavina \\ People Friendship's University of Russia, Russia \\ cross $^{\text {ref }}$ http://dx.doi.org/10.5755/j01.em.18.4.5726
}

\begin{abstract}
Purpose. This article provides analysis of the European Initial Public Offerings (IPO) market which is one of the biggest of the Global IPO markets. IPO provides a stock market launch, when shares of stock of a company are introduced to public at a stock exchange for the first time. IPO is an important source of finance resources for rapidly developing companies and a key step for them to become mature. Recent economic crisis has changed the landscape and the practice of IPO that should be reconsidered either from an investors point of view or from the company heading to the IPO. The article is also focused on identifying the roles of global and regional stock exchanges using example of development of London and Warsaw stock exchanges.

Methodology. The article provides quantitative analysis of selected top performing European stock exchanges official reports and analytical papers of key audit and consulting experts. It is particularly focused on a number of IPO's, volume of raised capital by year and by stock exchange within the period preceding the financial crisis of 2007-2008.

Results. The article shows changes in the European IPO dynamics and change of roles of the European stock exchanges in post financial crisis. In particular it shows the growth of importance of the regional stock markets in the European stock exchange ecosystem and Warsaw Stock Exchange (WSE).

Practical implications. Recent economic crisis has changed the landscape in the practice of making IPO's. Company heading to IPO should take changes on the IPO market seriously and take regional IPO opportunity into consideration. Presented results could help to streamline IPO plans. Results could be of interest to investors to have a more detailed look at the highly performing regional stock exchanges.

Value/originality. This article studies are based on the most current data collected by the author from the various stocks reports and the most respectable audit and consulting companies. Analysis and graphic materials are produced by the author.
\end{abstract}

The type of the article: Empirical study.

Keywords: IPO, initial public offering, stock exchange, stock market, LSE, WSE.

JEL Classification: B26; F01; F30; F65.

\section{Introduction}

The Initial Public Offerings market (IPO) is a part of the securities market, where issuers raise capital. Market demand is formed by investors, who purchase shares in IPO's, and the market supply is formed by issuers and shareholders, who need funds. In the article, the IPO market is considered to be a segment of the securities market, where a sale of shares by the issuer and the shareholders is accompanied by business transformation from private to the public.

The world market of IPO's reached its highest level in 2007. The global financial crisis of 2008-2009 caused a significant reduction in emission activity. During all the time the European IPO market was in top-three position, among with the markets of the United States and China. In 2010, Europe had the second largest number of deals and the third in the volume of the raised capital, and in 2011 the first in the number of offerings and the second in the volume of raised capital. While 
comparing the trends of the development of global and regional markets it can be noted that IPOs on the global market are shifting to the emerging markets. European Stocks are of a particular interest because combine both mature global stock exchanges as newly developed regional.

The major characteristics of the particular stock exchange are the number of IPOs and the volume of raised capital. For these reason, the objective of our study based on the European IPO market from 2005 to early 2013, is to provide an updated view of the European IPO market and in particular to provide answers to the following questions: What are the main trends on European IPO market? Is it enough to analyze main characteristics of the stock exchanges to range them due to the IPO market?

The first part of this paper describes the European IPO market by the main characteristics: number of IPOs, IPO offering value, International IPOs and description of the market by division to stock exchanges. This decryption identifies main trend on the market and helps to highlight the most developed and popular stock exchanges in the region. The second part focuses on two most developed stock exchanges of the European region.

The London Stock Exchange (LSE) has features of global stock exchange, and is one of the most popular markets among investors and issuers. But it is not necessary to have a status of global stock exchange to be a leader of the region IPO market. On the other hand, the characteristics of the Warsaw Stock Exchange (WSE) are typical for the most regional stock exchanges. WSE is an example of successful development of a regional stock exchange in a short period of time.

Modern empirical studies and research topics affecting the IPO do not contain a full description of the European IPO market and relationship between global and local European stock markets.

Gary Schwoltzer and Valentina Khmolovskih (2012) analyzed stock market listing requirements and fees among most popular stock exchanges on a global stock market. They described only two stock exchanges from Europe LSE and WSE.

More often the research topics focuses on the world largest stock Exchanges such as NYSE, LSE, NASDAQ and TSE, and do not pay special attention to the analysis market of the whole region. Ross Geddes in his book "IPOs and Equity Offerings" provided two chapters describing of US and UK regulation system of IPO market, and fragmental description of LSE and NYSE.

A short analysis and comparison of the Vienna Stock Exchange and Warsaw Stock Exchange - two regional stock exchanges on the European stock market by Anne d'Arcy, Igor Filatchev (2012) - provided quantitate and qualitative analysis of both stock exchanges. Rafat Sieradzki (2005) provided evidence of the short- and long-rung performance of investments and found the main determinants of the IPO returns. This research shows no description of the WSE IPO market and its position in the Europe IPO market.

There is a growing interest in developing regional markets, the attention of investors is attracted by WSE (Paleri, Redondi, 2006) The main source of latest actual information used to the article were the official publications of consulting and auditing firms such as Ernst\&Young, PriceWaterhouseCoopers and reporting material that is published annually in the Bulletin of the WSE. The collection of PWC reports "IPO Watch Europe Survey" sets out the description of European IPO market by the main characteristics from the 2008 up to the 1q. 2013. These reports do not touch the question of the listing teams and do not provide any type of market evaluation. More early statistics were described by Jane-Francois Gajewshi and Carde Gresse (2006). They tried to compare European and US IPO markets, they analyzed various features of the European IPO market: listing requirements, IPO-mechanism choices, and performance and secondary market liquidity. The main purpose of the article is to provide analysis of the European Initial Public Offerings (IPO) market, which is one of the biggest of the Global IPO markets.

\section{Method}

We united the data from different sources and used basic analysis methodology to indicate main trends on European IPO market. We used quantitative analysis that is based on use of quantitative data and qualitative method to interpret different characteristics and dependencies. Also 
we used comparative analysis to indicate leaders, trends and most developed stock exchanges on the European IPO market.

\section{European IPO market}

European IPO market reached its maximum in 2006, after which it became volatile, unstable and unpredictable. Europe "struck" World Financial Crisis of 2008-2009, the negative echoes of which still have an impact on the Global and European economies. Since 2010 IPO market of Europe began to show positive trends, but results of 2006 haven't been reached again. Despite the positive forecasts and positive activity in the market in 2012, Europe plunged in the new Financial Crisis, which broke the IPO market development in both Europe and the world.

In order to show an overall picture of the IPO market development in Europe, it should be mentioned that in 2006 the European stock exchanges realized 806 offerings with total value of more than $€ 87$ billion. In comparison, in 2009 when the European market reached its minimum, only 126 companies came out to the market for initial public offerings and totally were raised $€ 7,1$ billion. (see Figure 1)

Thus, 2010 became a first year of the European IPO market that had a positive trend after 2009 crisis. In 2009126 offerings were carried out, which raised $€ 7,112$ billion; in 2010 - 380 offerings with a total value of $€ 26,289$ billion (IPO Watch Europe Survey: 2010, 2011). We can say that the number of placements increased by more than three times in 2010 , and the amount of funds raised increased almost four times in comparison with 2009.

So year 2010 began to show signs of recovery, but nonetheless the performance of 2006 and 2007 remained the highest achievement in history of the European IPO market. The market capitalization of the companies also increased in 2010. In 2009, the market capitalization amounted $€ 7,934$ billion, in 2010 - already $€ 8,409$ billion with an increase of 6\% (IPO Watch Europe Survey: 2010, 2011). London SE Group and NYSE Euronext markets continued to be leaders by market capitalization in Europe - 53\% in total in 2010 (2009 - 49\%) (IPO Watch Europe Survey: 2010, 2011).

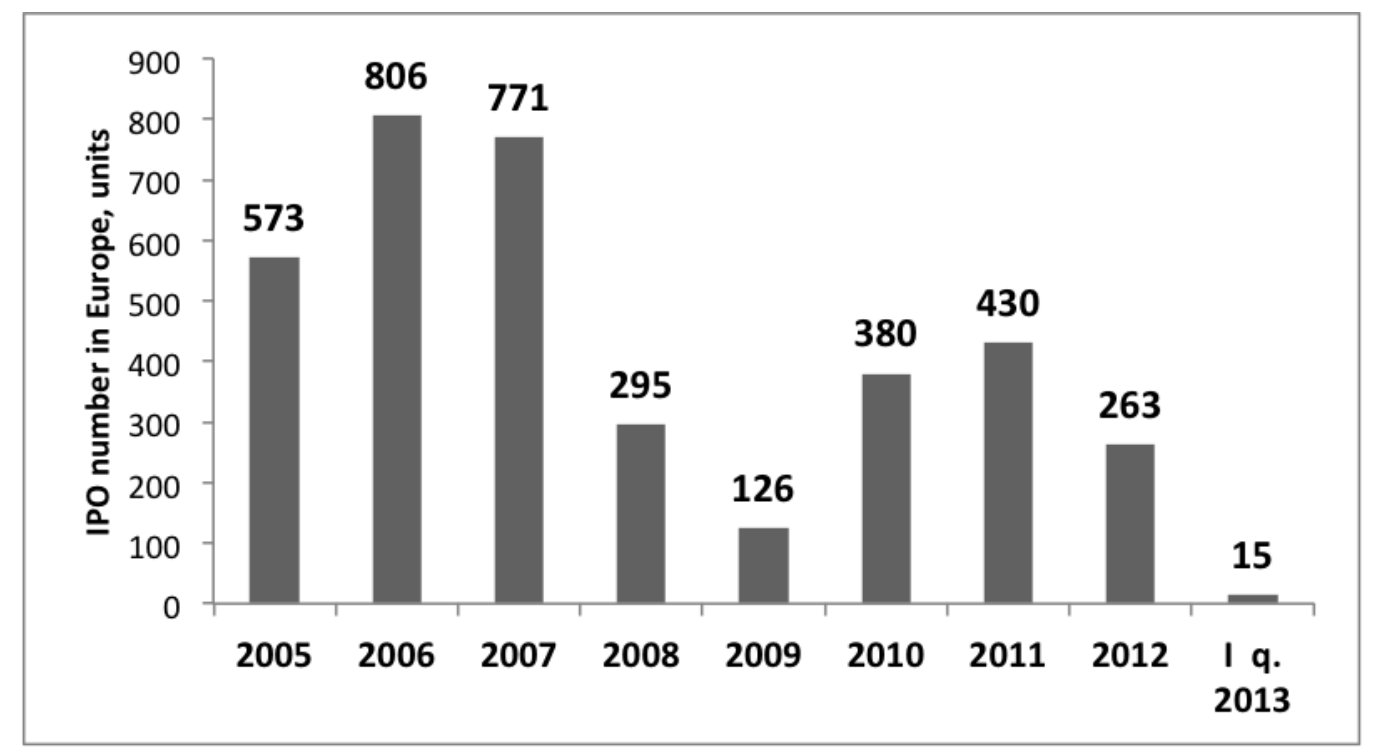

Figure 1. Number of IPO's in Europe, 2005 - I q. 2013

2011 also started with a positive momentum, but weak economy and political instability had a negative impact on the economy of European Union. Many planned deals were postponed to the next year, or eliminated altogether. However, 2011 carried out 430 IPO transactions (13\% more than in 2010) and raised a total of $€ 26,5$ billion (1\% more than in 2010) (IPO Watch Europe Survey: 2011, 2012).

More than a half of all transactions were carried out at WSE, 203 IPO offerings. But the offering value were smaller, offerings on WSE raised a total of $€ 2,2$ billion, for example the offerings on LSE raised $€ 14,1$ billion. Thus only one-quarter of all placements was held in London 
(IPO Watch Europe Survey: 2011, 2012). Year 2011 can be characterized by major transactions: the result of six largest initial public offerings raised $€ 16$ billion, representing $60 \%$ of total funds raised in European IPO market compared with $37 \%$ in 2010 (€9,6 billion). ("IPO Watch Europe Survey: 2011”, 2012) European IPO market of 2011 can be characterized by delayed offerings: almost $90 \%$ of companies chose to postpone or even cancel their placements. 25 companies announced their intentions to hold initial public offering, with a volume of more than $\$ 200$ million, 13 of them were either postponed or cancelled, $52 \%$ of all "applications".

Generally, during 201191 companies announced their intentions to hold IPO's and in the same year 22 companies cancelled their decisions, making a record for the last five years. (see Figure 2.)

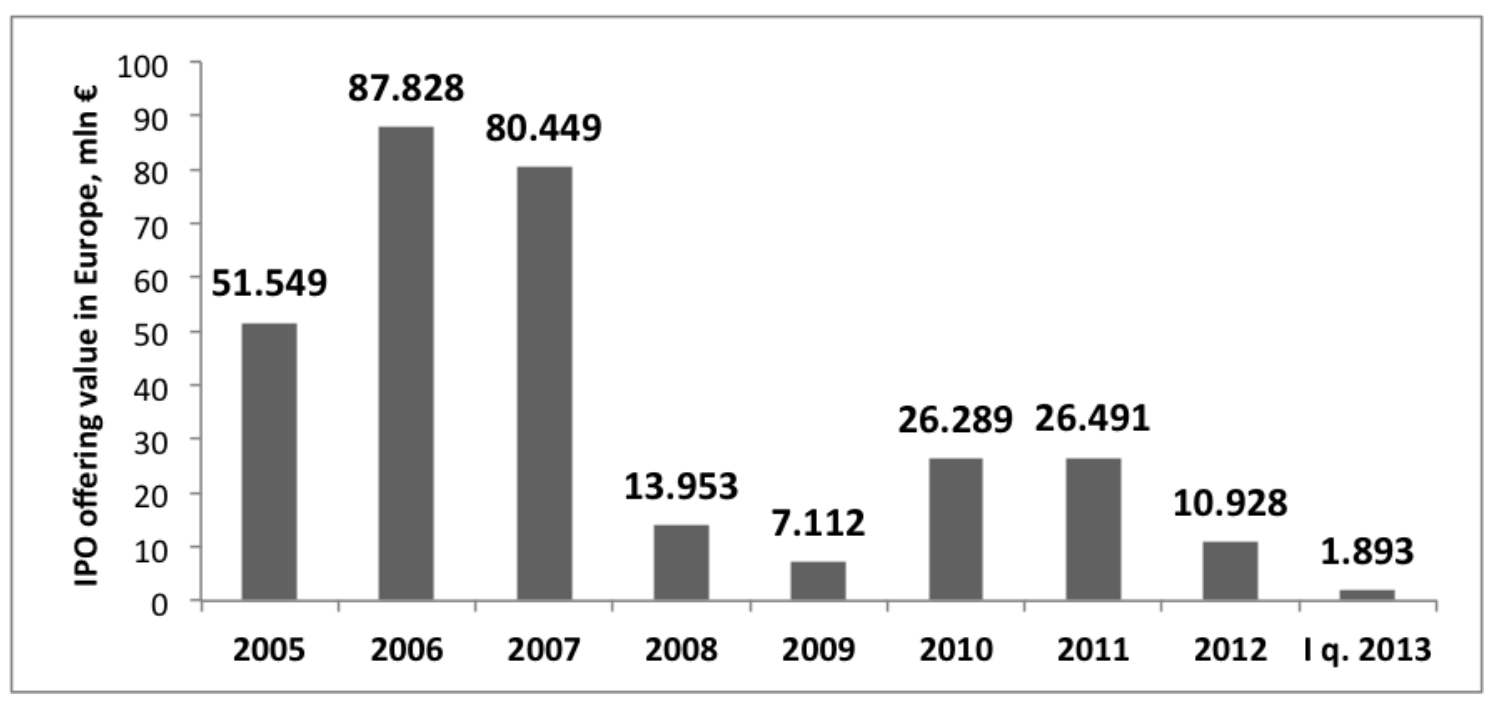

Figure 2. Volume of raised capital by IPO in Europe, mln. €, 2005- I q. 2013

Political and economic instability in Europe has influenced the Global IPO market and many companies preferred to postpone their listings to a more stable and profitable future. Many investors tried to hold back their money and preferred to buy stocks of giant companies - this also influenced the Global IPO market activity.

It should also be noted that 2012 was not a turning year: 263 IPO's were realized during the first three quarters in Europe, which attracted almost $€ 10.928$ billion. In the beginning of 2012 total volume of realized offerings fell because of the low market activity. The most popular markets for listing were LSE and WSE.

In the first quarter of 2013 on European stock exchanges $€ 1.8$ billion was raised within 15 IPO, accounting for $15 \%$ of the total funds raised in the global IPO market in the current quarter. This is 4\% lower indicator of capital raised in Q1 of 2012: 39 deals, raised more than $€ 2$ billion, which is $69 \%$ below the level of involvement of Q4 of 2012 (34 IPO's, raised capital - €6.3 billion).

\section{European Stock Exchanges}

European stock exchanges can be divided into two groups: EU-regulated and Exchangeregulated. EU-regulated markets demonstrated a sustainable recovery from the global financial crisis, however, the results of 2007, at the moment, have not been reached (see Table 1.)

2009 was the first year that showed a positive trend of activity growth on EU-regulated stock exchanges. Only 41 IPO's were realized in 2009, with total value of $€ 4,34$ billion (IPO Watch Europe Survey: 2011, 2012). It should be noted that the highest activity on the European stock exchanges was observed in 2010, with exception of Athens, Luxembourg Stock Exchanges and Euronext, which have not given any improvement. Problems with the activity on the Athens Stock Exchange (ASE) can be explained by a general decline in the economy of Greece, due to the possibility of default. However, number of IPO's has grown on the Luxemburg Stock Exchange and 
Euronext, but these offerings cannot be compared with IPO's in 2009. For example: in 2009, Delta Lloyd deal was implemented on Euronext raising $€ 1,016$ billion (IPO Watch Europe Survey: 2010, 2011). In 2010130 deals were realized on EU-regulated markets raising a total of $€ 23,59$ billion, in 2011 - 118 deals totalling €24,69 billion (IPO Watch Europe Survey: 2011, 2012). Two largest European stock exchanges, LSE (main market) and Spanish Stock Exchange, were the only exchanges, among EU-regulated exchanges, that raised more capital in 2011 than in 2010 (IPO Watch Europe Survey: 2011, 2012).

Table 1. European IPO market: analysis of the exchanges

\begin{tabular}{|c|c|c|c|c|c|c|c|c|}
\hline \multirow[b]{2}{*}{ Stock Exchange } & \multicolumn{2}{|c|}{2009} & \multicolumn{2}{|c|}{2010} & \multicolumn{2}{|c|}{2011} & \multicolumn{2}{|c|}{ I q. 2012} \\
\hline & 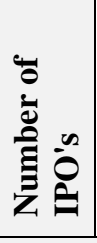 & 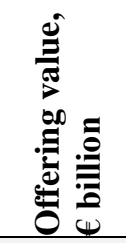 & 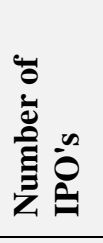 & 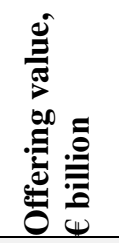 & 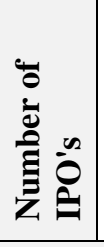 & 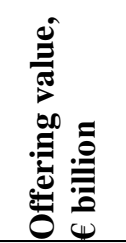 & 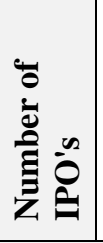 & 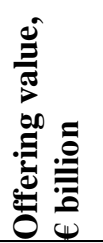 \\
\hline \multicolumn{9}{|c|}{ EU-regulated } \\
\hline London Stock Exchange, LSE (Main) & 9 & 0,620 & 52 & 9,034 & 39 & 13,371 & 7 & 0,569 \\
\hline Warsaw Stock Exchange,WSE (Main) & 12 & 1,584 & 26 & 3,770 & 31 & 2,067 & 4 & 0,008 \\
\hline Oslo Bors & - & - & 9 & 2,362 & 4 & 0,551 & - & - \\
\hline Deutshe Borse & 1 & 0,048 & 10 & 2,297 & 13 & 1,445 & - & - \\
\hline Borsa Italiana (Main market) & 1 & 0,105 & 2 & 2,099 & 3 & 0,494 & - & - \\
\hline NASDAQ OMX (Main market) & 6 & 0,066 & 15 & 2,007 & 13 & 0,288 & 1 & - \\
\hline BME (Spanish Exchange) & 1 & - & 2 & 1,514 & 4 & 6,070 & - & - \\
\hline NYSE Euronext (Euronext) & 6 & 1,907 & 11 & 0,344 & 8 & 0,043 & 6 & 0,972 \\
\hline SIX Swiss Exchange & 4 & - & 4 & 0,163 & - & - & 1 & 0,681 \\
\hline Athen Stock Exchange, ADE & 1 & 0,010 & - & - & - & - & - & - \\
\hline Wiener Borse & - & - & - & - & 2 & 0,366 & - & - \\
\hline Borse de Luxembourg & - & - & - & - & - & - & 1 & - \\
\hline Irish Stock Exchange, ISE & - & - & - & - & - & - & - & - \\
\hline Sub-Total & 41 & 4,340 & 130 & 23,590 & 118 & 24,695 & 20 & 2,230 \\
\hline \multicolumn{9}{|c|}{ Exchange-regulated } \\
\hline $\begin{array}{l}\text { London Stock Exchange, LSE } \\
\text { (Alternative) }\end{array}$ & 14 & 0,655 & 58 & 1,180 & 60 & 0,516 & 9 & 0,052 \\
\hline Luxemburg Stock Exchange (EuroMTF) & 22 & 1,575 & 36 & 0,797 & 20 & 0,451 & - & - \\
\hline London Stock Exchange, LSE (SFM) & 1 & 0,030 & 4 & 0,305 & 2 & 0,217 & - & - \\
\hline Deutshe Borse ("Entry" standart) & 4 & 0,005 & 13 & 0,116 & 5 & 0,078 & 1 & - \\
\hline Oslo Axess & 2 & 0,091 & 7 & 0,083 & 9 & 0,264 & - & - \\
\hline NYSE Euronext (Alternext) & - & - & 21 & 0,073 & 19 & 0,111 & 2 & 0,003 \\
\hline BME (MAB) & 2 & 0,019 & 10 & 0,048 & 5 & 0,013 & 3 & 0,006 \\
\hline $\begin{array}{l}\text { Warsaw Stock Exchange, WSE } \\
\text { (NewConnect) }\end{array}$ & 26 & 0,010 & 86 & 0,040 & 172 & 0,133 & 21 & 0,006 \\
\hline Borsa Italiana (AIM) & 5 & 0,032 & 6 & 0,032 & 3 & 0,009 & - & - \\
\hline ESM & - & - & - & - & 1 & 0,017 & - & - \\
\hline NASDAQ OMX ( First North) & - & - & 9 & 0,022 & 17 & 0,004 & 2 & 0,002 \\
\hline London Stock Exchange, LSE (PSM) & 1 & 0,355 & - & - & - & - & - & - \\
\hline Sub-Total & 85 & 2,772 & 250 & 2,696 & 312 & 1,796 & 38 & 0,069 \\
\hline Europe Total & 126 & 7,112 & 380 & 26,286 & 430 & 26,491 & 58 & 2,299 \\
\hline
\end{tabular}

Source: adapted by the author with reference to PWC reports

On an exchange-regulated markets, 312 deals were realized in 2011 raising $€ 1,796$ billion, while in 2010 only 250 deals were realized ( $€ 2,69$ billion) and in 2009 - 85 IPO's ( $€ 2,772$ billion) (IPO Watch Europe Survey: 2011, 2012). This means that, compared to 2010, the number of deals 
on an exchange-regulated markets increased by $24 \%$, and the level of raised funds decreased by 33\% (IPO Watch Europe Survey: 2011, 2012).

Majority of the largest deals in the first three quarters in 2012 were held at the LSE. Two third of deals were held on an exchange-regulated markets, where $90 \%$ of the capital on EU-regulated markets has been raised.

At the moment, London remains the undisputed leader in the attractiveness of the initial public offerings, both for national and international companies as well as one of the biggest world financial centres. It should also be mentioned that the global financial crisis has affected the activity on the London IPO market. Despite the fact that other major European stock exchanges suffered less, London recovers faster than other markets. Main market of LSE reached its minimum in 2009 when only 9 IPO transactions were held for a total $€ 0,620$ billion, and in 201052 deals were completed in the amount of $€ 9,034$ billion allowing the LSE to take the first place among other European exchanges (IPO Watch Europe Survey: 2011, 2012). Thus in 2011, the LSE held a 30\% share of the total number of IPO deals in Europe (IPO Watch Europe Survey: 2011, 2012). Total income from IPO deals increased by $€ 3,585$ billion in London in $2011,34 \%$ more than in 2010 (IPO Watch Europe Survey: 2011, 2012). Much of this amount has been raised as a result of initial public offering of Glencore, which was able to attract $€ 6,86$ billion, representing almost half (49\%) of the total capital raised on the LSE (IPO Watch Europe Survey: 2011, 2012). The situation repeated in 2011 when LSE took the first place again among other European markets with 101 IPO deals realized on its grounds raising $€ 14,104$ billion (IPO Watch Europe Survey: 2011, 2012). In 2011, LSE held 24\% share of the total number of placements in Europe (IPO Watch Europe Survey: 2011, 2012).

There was low activity on the LSE during the first three quarters of 2012. This fact can be associated with the Olympic Games that were held in London, that diverted investors' attention. However, activity indicators in European stock market were significantly affected by Sberbank offering, Russian largest commercial bank, which rose $€ 4,050$ billion on the main market of LSE.

In 2009, WSE was ranked first by the number of IPO deals, 38 offerings were carried in the amount of $€ 1,594$ billion. The WSE share of the total number of IPO's was $30 \%$, and share of the total funds raised was 22\% (IPO Watch Europe Survey: 2010, 2011). €3,818 billion (more than double in 2009) was raised on WSE in 2010 as a result of 112 deals (almost three times more than in 2009) (IPO Watch Europe Survey: 2010, 2011). The proportion of total number of IPO's decreased to $29 \%$ in 2010, while the share of the funds raised - 14\% (IPO Watch Europe Survey: 2010, 2011). The WSE held two IPO's in 2010, aimed at the privatization of large state-owned companies: PZU (insurance company) and Tauron Polska Energia (energy company), that were able to raise $€ 1,990$ billion and $€ 1,026$ billion, respectively (IPO Watch Europe Survey: 2010, 2011). WSE increased number of realized IPOs by 19\% in 2011 (compared to 2010) - 203 deals for a total of $€ 2,2$ billion (IPO Watch Europe Survey: 2011, 2012). Initial public offering of Jastrezbska Spolka Weglowa became the largest deal on WSE, and the fourth-largest deal in Europe, it raised $€ 1,346$ billion (IPO Watch Europe Survey: 2011, 2012).

NYSE Euronext could not boast with good results in 2009, where only 6 IPO's were carried out raising $€ 1,907$ billion. In 2010 , however, the stock exchange took the fourth place in the number of deals in Europe - 32 deals, but dropped to the ninth place in total value of transactions - €0,417 billion (IPO Watch Europe Survey: 2010, 2011).

In 2011 the following stock exchanges: Oslo Bors, NASDAQ OMX, NYSE Euronext and Swiss Stock Exchange decreased the number of realized IPO's by $31 \%$ to 27 deals and raised funds by $31 \%$ to $€ 0,882$ billion compared with 2010 (IPO Watch Europe Survey: 2011, 2012).

23 IPO's were realized ( $6^{\text {th }}$ place) at the German stock market (Deutshe Borse) raising $€ 2,413$ billion ( $4^{\text {th }}$ place) in 2010 (IPO Watch Europe Survey: 2010, 2011). These figures exceeded the results of 2009 when the German Stock Exchange realized five deals for $€ 0,0053$ billion, which is almost 50 times less than in 2010 (IPO Watch Europe Survey: 2010, 2011). Thus, the share of total raised capital on the European market has increased by $9 \%$ at Deutshe Borse (IPO Watch Europe Survey: 2010, 2011). Market share of the number of placements in the European IPO market 
increased from 4\% in 2009 to $6 \%$ in 2010 (IPO Watch Europe Survey: 2010, 2011). The largest transaction on that exchange (main floor) was Kabel Deutschland IPO, the company raised $€ 0,660$ billion (IPO Watch Europe Survey: 2010, 2011). In addition this initial public offering was the tenth largest deal of all placements in 2010 year in Europe.

Only eight IPO's were realized on the Italian Stock Exchange (Borsa Italiana) in 2010 raising $€ 2,131$ billion, 15 times more than in 2009 when six placements raised $€ 0.137$ billion (IPO Watch Europe Survey: 2010, 2011). Thanks to the largest offering of 2010 in Europe, most of the raised capital for the co-location on the Spanish and Italian markets, where Enel Green Power (electricity company) completed an initial public offering, through which the company raised $€ 2,264$ billion (IPO Watch Europe Survey: 2010, 2011), of which $€ 2,067$ billion had been received in Italy, accounting for $97 \%$ of all funds raised on the Italian Stock Exchange (IPO Watch Europe Survey: 2010, 2011).

The Spanish Stock Exchange (BME) showed a positive trend. In 2009, there were three initial public offerings that raised $€ 0,019$ billion, while in 2010 - 12 deals totalling $€ 1,562$ billion (IPO Watch Europe Survey: 2010, 2011). As a result, in 2010 the Spanish Stock Exchange had a market share by number of deals of 3\%, where a market share by value of deals increased to 6\% (IPO Watch Europe Survey: 2010, 2011). It is also worth to mention that the Spanish Stock Exchange had the best performance in 2011: the value of placements on the exchange was $€ 6,083$ billion (more than three times more than in 2010), though the number of completed deals was only nine (IPO Watch Europe Survey: 2010, 2011).

36 placements that have raised $€ 0,797$ billion in 2010, allowed the Luxembourg Stock Exchange to take the third place in the number of IPO's (IPO Watch Europe Survey: 2010, 2011). Year 2009 wasn't that productive. As a result, only 22 transactions were realized on the Luxembourg Stock Exchange valued at $€ 1,575$ billion, so the results of 2010 increased by $61 \%$ in number of deals and by $51 \%$ of their value (IPO Watch Europe Survey: 2010, 2011). Market share of the Luxembourg Stock Exchange by number of deals fell from 17\% to 9\%, and has dramatically decreased by value - from 22\% to 3\% (IPO Watch Europe Survey: 2010, 2011).

\section{International IPO's}

Initial public offerings of companies with registration outside of Europe are referred to as International IPO's in Europe.

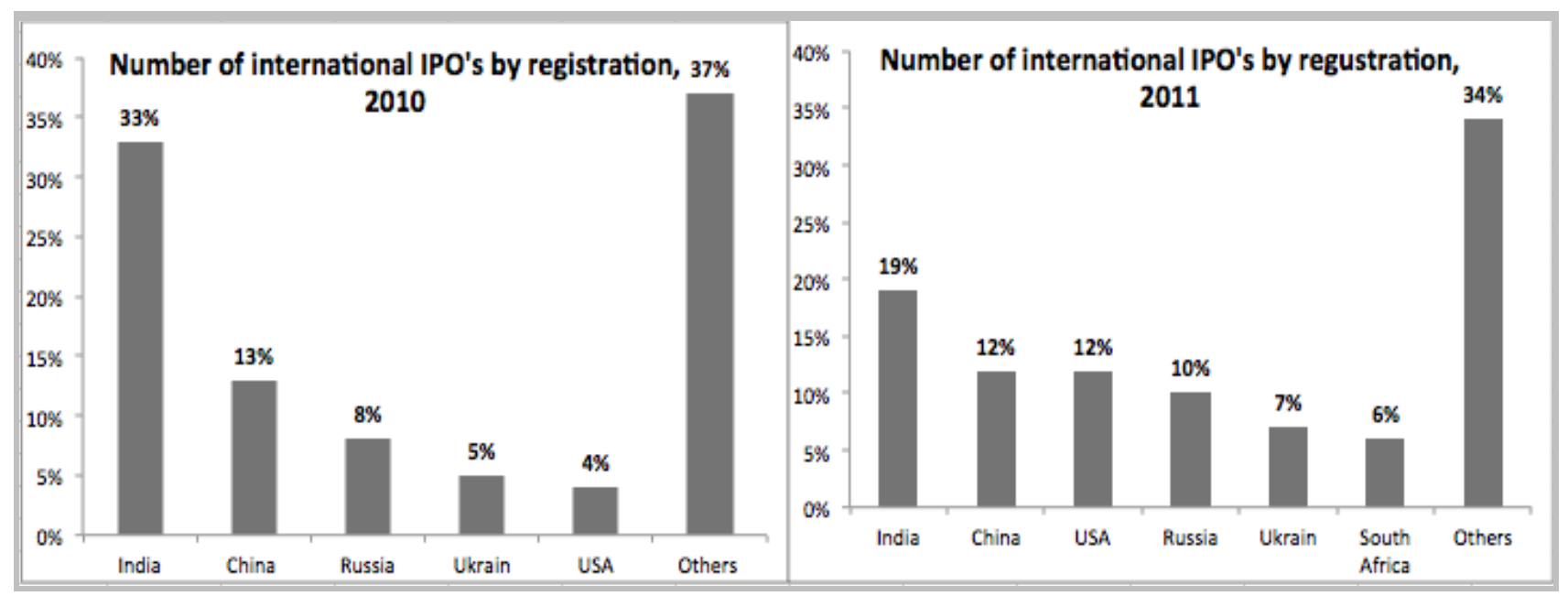

Figure 3. Number of international IPO's, by country of registration

100 international IPO's raised $€ 8,714$ billion by the end of 2010 (IPO Watch Europe Survey: 2010, 2011). Financial crisis of 2008-2009 has not had a significant impact on the activity of the international IPO's in Europe, the level of market activity of international deals remained relatively high mostly because of listings of Indian depositary receipts. Share of Indian companies in 
international deals on the European stock Exchanges was 33\% in 2010, and only 19\% in 2011 (IPO Watch Europe Survey: 2010, 2011). Their share of the total value of raised funds by international IPO's was 34\% in 2010 and 5\% in 2011 (IPO Watch Europe Survey: 2010, 2011). China follows India - deals of the Chinese companies took $13 \%$ of the total number of international IPO's and $18 \%$ of the total raised capital by international IPO's in 2010 (IPO Watch Europe Survey: 2010, 2011). The results of the listings of the Chinese companies have sharply deteriorated in 2011; their share of the number of placements was $12 \%$, while the share of the total funds raised was only $4 \%$ (IPO Watch Europe Survey: 2011, 2012) (see Figure 3.)

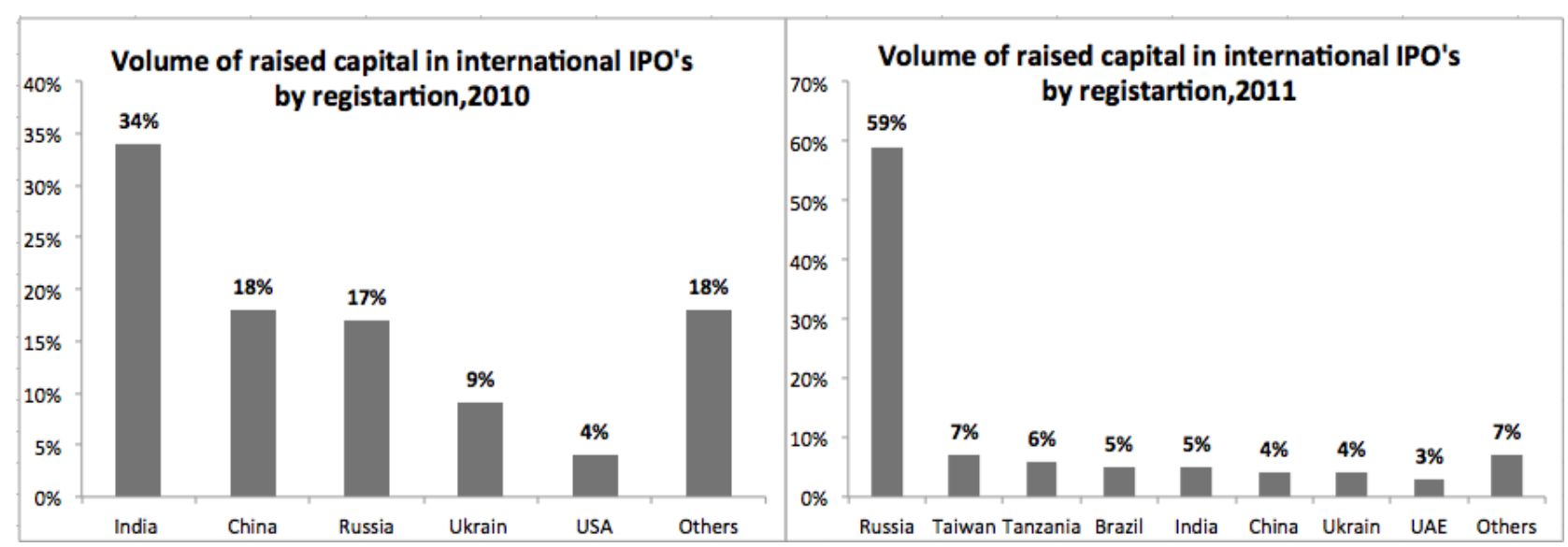

Figure 4. The volume of the raised capital by international IPO's, by registration, 2010 to 2011

The performance of international IPO's in Europe dramatically decreased in 2011: the amount of raised capital decreased by $48 \%$ to $€ 4,597$ billion. (IPO Watch Europe Survey: 2011, 2012) This behaviour can be explained by the absence of large placements in this segment of the market. The number of cross-border IPO's was almost unchanged compared to 2010, and amounted to 96 IPO deals (see Figure 4.)

It is worth to mention that in this segment in 2011 a significant role played companies from Russia, whose listings occupied the first five positions. Companies from Russia prefer to do their placements on the LSE: JSC "FosAgro" NomosBank Ploymetal International Etalon Group limited, Global ports Investments. The aggregate amount of funds raised by these companies amounted to $59 \%$ of the total volume (IPO Watch Europe Survey: 2011, 2012). It should also be noted that, in comparison with 2010, the share of Russian companies in the number of transactions was $8 \%$, while the number of transactions in 2011 increased and reached 10\% (IPO Watch Europe Survey: 2011, 2012).

Currently we see an increasing competition between stock exchanges of the world. Stocks pass through a series of merge and acquisitions in order to grow bigger, to enter regional markets and to diversify their businesses.

\section{Regional and global stock exchanges}

There are two key ways of regional stock development: either through merges and acquisitions or through expansion capabilities through better correspondence to regional payment and depositary systems, offering clear terms of listings to regional clients, providing fair exchange rates, increasing the number of traded financial instruments and attracting investors to ensure fair stock prices.

It should also be noted that the majority of regional stock exchanges focus on trading in local currencies while global stock exchanges trade in key international currencies such as U.S. dollar or EURO. Still the role of the regional stock exchanges as well as their ability to stand in the view of the global stock monsters is under the question.

A comparison of the WSE, one of the most successful regional stocks, with the LSE, the biggest in Europe, could give an answer. Currently WSE is the second after LSE in the number of transactions carried at a particular stock exchange (see Table 2 and Figure 5.) 
Table 2. Number of IPO's

\begin{tabular}{|c|c|c|c|c|c|}
\hline & $\mathbf{2 0 0 8}$ & $\mathbf{2 0 0 9}$ & $\mathbf{2 0 1 0}$ & $\mathbf{2 0 1 1}$ & I-II q. 2012 \\
\hline London Stock Exchange, LSE & 99 & 24 & 114 & 101 & 54 \\
\hline Warsaw Stock Exchange, WSE & 91 & 38 & 112 & 203 & 87 \\
\hline
\end{tabular}

Source: adapted by the author with reference to PWC reports

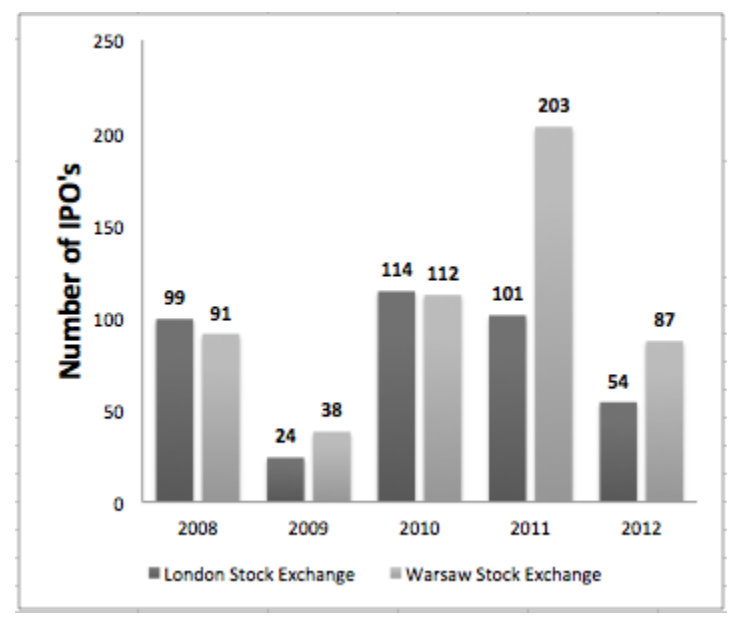

Figure 5. Number of IPO's

Starting from 2008 a number of listings carried out at WSE was almost equal to the number of listings at LSE and starting from 2011 a number of listings on WSE significantly exceeds a number of listings on LSE. (see Table 3. and Figure 6.)

Table 3. Raised capital, mln. $€$

\begin{tabular}{|c|c|c|c|c|c|}
\hline & $\mathbf{2 0 0 8}$ & $\mathbf{2 0 0 9}$ & $\mathbf{2 0 1 0}$ & $\mathbf{2 0 1 1}$ & I-III q. 2012 \\
\hline London Stock Exchange, LSE & 8.884 & 1.305 & 10.519 & 14.104 & 5.428 \\
\hline Warsaw Stock Exchange, WSE & 2.502 & 1.594 & 3.81 & 2.2 & 78 \\
\hline
\end{tabular}

Source: adapted by the author with reference to PWC reports

In the view of the money raised in the course of IPO process on both exchanges there is no doubt that the results of LSE are far greater than of WSE since WSE targets relatively small local companies.

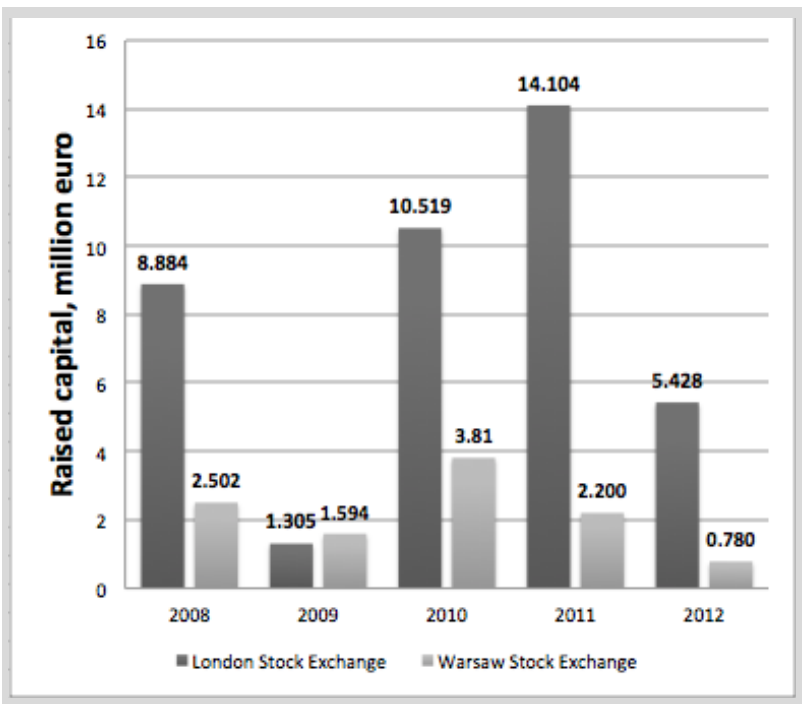

Figure 6. Raised capital, $\operatorname{mln} €$ 
There are a number of factors that influenced WSE's success. Investors see WSE as a regional site that links countries of Central and Eastern Europe. On the contrary, LSE is associated with global companies from key developed countries. WSE provides a real opportunity for mid-sized companies to do an initial public offering. Its listing terms are easier compared to LSE. Average listing at WSE could cost 5-6\% of the raised funds, while listing at LSE could cost up to $20 \%$. It should be understood that mentioned features of WSE are also the characteristic features of most of the regional stock exchanges.

Thus, Global financial crisis of 2008-2009 still affects the global market of IPO's, including the market of initial public offerings in Europe. Also, the market continues to deny the influence of instability in Europe and its debt crisis and the high volatility of the markets in the world. In addition, influenced by the negative trend of slowing growth in the world economy and China's economy. All these factors reduced the confidence of investors. As a result, a large number of companies were planning to hold IPO, postponed their deals waiting for a better situation on the market, or even cancelled them. Strengthening market confidence, especially while reducing financial risks in major economic regions, including UK and Germany, creates favourable prospects.

Governmental innovations on the European market will be important and will be aimed to facilitate the access to the market for high-growth companies. It will be a positive signal to companies and investors, and will open a new path on the IPO market. Thus the current situation will affect the practice of holding an IPO in Europe. The IPO market is totally dependent on the economic system as a whole, so the IPO market will not be able to stabilize and show positive results as long as the economy starts to do the same. Because of the unstable situation on the market the issuers will try to find alternative sources of capital that are not accompanied by such high risks. Companies that already decided for themselves that an IPO is the only possible solution, will have to become more flexible and adapt to the market. It is expected that the high volatility of the market will gradually decline, and favourable for listings «window» will appear on the market in the near future.

In addition, it is expected that European companies that occupy strong positions on the market will prefer Asian markets as a venue for initial public offerings. It should also be noted that, according to Klaus Hessenberg, European companies will resort more and more to the method of the United States, where the IPO process is more compressed and fast.

\section{Discussion}

The major objective of this paper is to provide the description of European IPO market between 2005 and early 2013 and to identify the key trends on the market. The European IPO market is one of the biggest in Global IPO market, and it has 13 stock exchanges. As well as Global IPO market Europe has reached it highest level in 2007 before the World finance crisis of 20082009. The "black" period of the world economy caused consequences and emission activity went down. The shares prices, the stock exchange indices, the number of IPOs and volume of raised capital also collapsed. Then European IPO market was in center of Europe financial crisis that also slowed its development. In spite that fact European IPO market since 2005 till now is still among top-3 biggest IPO markets in the world, with China and US.

Regional stock exchange, in particular WSE, show greater vulnerability to global economy turmoil and studies show deeper levels of negative impact and longer period of recovery of regional stock exchanges, if compared with global stock exchanges. This could be partly explained by the mobility of the global companies on the global stock exchanges that operate worldwide and can leverage losses at depressed markets with greater effort on the active markets. Regional companies in turn are doomed to follow the general trend of the economy of the depressed region. The local investors are less mobile than the global. This fact also could cause deeper and longer crisis period on regional stock exchanges.

European stock market has two types of stock exchanges: EU-regulated and exchangeregulated, due to our comparative analysis we identified main stock exchanges: London Stock 
Exchange and Warsaw Stock Exchange. The LSE is one of the worlds largest, oldest and one of the most popular stock exchange in the world as among investors as issuers and companies. That caused to the position of global stock exchange, and LSE is focused to the biggest worldwide known companies. LSE was the leader of the European region, now it is only the leader by the amount of raised capital. The WSE is the regional stock exchange targeted to mid-companies and small companies, which are looking for regional investors, became the biggest in the Europe by the number of IPOs.

Our analysis showed that regional stock exchange could compete with global stock exchanges. The LSE the leader of the region has less number of IPOs then WSE. So Warsaw Stock Exchange is more developed by several facts and can be competitive to the market leader by dynamics of development, by attractiveness to the small companies, by the IPO number. Quantitative and comparative methods of analysis are not enough to clearly identify the leader on the Europe IPO market, that needs further navigation.

\section{References}

Paleari, S., Redondi, R., Piazzalinga, D. \& Vismara, S. (2006). Academic eur IPO fact book 2006, Charleston, CA: Booksurge Publishing.

Schwoltzer, G. \& Khmolovskih, V. (2012). Comparing global stock exchanges. Russia: Erst\&Young. Retrieved July 17, 2013, from http://www.ey.com/Publication/vwLUAssets/Comparing-global-stockexchanges-eng-2012/\$FILE/Comparing-global-stock-exchanges-eng-2012.pdf

Gajewshi, J-F. \& Gresse, C. (2006). A survey of European IPO market. (ECMI №2). Brussels, Belgium: Centre for European Policy Studies. Retrieved from http://mercury.ethz.ch/serviceengine/Files/ISN/29614/ipublicationdocument_singledocument/a3f28b9 4-434e-4d2f-8497-9765b7af8129/en/002_A+Survey+of+the+European+IPO+Market.pdf

Pegano, M., Roel, A. \& Zechner, J. (2002). The geography of equity listing: Why do companies list abroad?. Journal of Finance, 57(6), 2651-2694. doi:10.1111/1540-6261.00509

Gendess, R. (2003). IPO's and equity offerings. Burlington, MA: Butterworth-Heinemann.

Sieradzki, R. (2013). Does it pay to invest in IPO's? Evidence from the Warsaw stock exchange. Warsaw, Poland. National Bank of Poland (working paper №139), Retrieved from http://www.nbp.pl/publikacje/materialy_i_studia/139_en.pdf

Filatotchev, I., d'Arcy, A., Moser, R. \& Lindorfer, R. (2013). The globalization of capital markets and competitiveness of the Vienna stock exchange. WU University of Economics and Business. Retrieved from http://www.wu.ac.at/icg/bericht_borse

Blowers, S. C., Griffith, P.H. \& Milan, T. L. (1999). The Ernst\&Young guide to the IPO value journey. John Willey and Sons.

Trowbridg, T. \& Weaver, R. (2011). IPO watch Europe survey: Review of 2010. United Kingdom. PricewaterhouseCoopers. Retrieved from http://www.pwc.ru/en_ru/ru/capitalmarkets/assets/ipo_watch_europe_2010.pdf

PricewaterhouseCoopers. (2012). IPO watch Europe survey: 2011. Retrieved from https://www.pwc.com/en_UA/ua/services/capital-markets/assets/ipo-watch-europe-2011-ua-en.pdf

PricewaterhouseCoopers. (2012). IPO watch Europe survey 1q. 2012. Retrieved form http://informarket.ru/research/obzor_rinka_ipo_v_evrope_i_kvartal_2012g_.pdf

PricewaterhouseCoopers. (2012). IPO watch Europe survey 2q. 2012. Retrieved form http://www.accountancynieuws.n1/Uploads/Files/pwc-ipo-watch-q2-2012.pdf

PricewaterhouseCoopers. (2013). IPO watch Europe survey 4q. 2012. Retrieved form http://www.pwc.de/de_DE/de/kapitalmarktorientierte-unternehmen/assets/pwc-ipo-watch-q4-2012.pdf

Ernst\&Young. (2013). Global IPO trends 2012: Prepare early move fast. United Kingdom. Retrieved form http://www.ey.com/Publication/vwLUAssets/Global_IPO_trends_2012/\$FILE/Global_IPO_trends_20 12.pdf 